\title{
Acute Calcific Tendinitis of the Gluteus Medius
}

\author{
Gluteus Mediusun Akut Kalsifik Tendiniti
}

\author{
(1) Berke Aras, (1) Serdar Kesikburun*, (1) Ümüt Güzelküçük*, (1) Evren Yaşar*, (1) A. Kenan Tan* \\ Kastamonu Rehabilitation Centre, Kastamonu, Turkey \\ *University of Health Sciences, Gülhane Medical School, Gaziler Physical Therapy and Rehabilitation Research and Training Hospital, Ankara, Turkey
}

\section{Abstract}

Calcific tendinitis is an inflammatory condition occurring in numerous anatomic locations. Involvement of the gluteus medius tendon is uncommon. In this case we report a patient with hip pain due to calcific tendinitis of the gluteus medius tendon. A 39-year-old male patient was admitted to our outpatient clinic with a complaint of severe right hip pain, which persisted for two weeks and exacerbated with activity. Physical examination revealed marked tenderness around the right greater trochanter. On magnetic resonance imaging, inflammatory edematous changes were demonstrated in the region of the greater trochanter insertion of the gluteus medius tendon. Non-steroidal antiinflammatory drug was started to the patient by the diagnosis of acute calcific tendinitis. The patient reported no reduction in pain one week after the drug therapy. Thereafter, a corticosteroid injection to the lesion site was administered and patient's symptoms decreased within three days. Clinicians should keep in mind the calcific tendinitis of the gluteus medius muscle in the differential diagnosis of hip pain. The diagnosis is made by physical examination and radiological findings of calcific deposits in the related tendon.

Keywords: Calcific tendinitis, hip pain, steroid injection

\section{Öz}

Kalsifik tendinit bir çok anatomik noktada oluşabilen enflamatuvar bir durumdur. Gluteus medius tendonun tutulumu nadiren görülür. Bu olguda gluteus medius tendonunun kalsifik tendinitine bağlı kalça ağrısı olan bir hasta takdim edilecektir. Otuz dokuz yaşında erkek hasta polikliniğe 2 haftadır devam eden ve aktivite ile artan şiddetli sağ kalça ağrısı şikayeti ile başvurdu. Fizik muayenesinde sağ tronkanter major çevresinde belirgin hassasiyet saptandı. Manyetik rezonans görüntülemede gluteus medius tendonunun trokanter majore bağlanma bölgesinde enflamatuvar ödematöz değişiklikler saptandı. Akut kalsifik tendinit tanısı ile hastaya non-steroid anti-enflamatuvar ilaç başlandı. Bir haftalık ilaç tedavisine rağmen ağılarında azalma olmadı. Daha sonra kortikosteroid yapılan hastanın semptomlarında üç gün içinde azalma gözlendi. Klinisyenler kalça ağrısının ayıııı tanısında gluteus medius kasının kalsifik tendiniti de akılda tutmalıdırlar. Tanısı fizik muayene ve ilgili tendonda kalsifik birikmelerin radyolojik bulguları ile konur.

Anahtar kelimeler: Kalsifik tendinit, kalça ağrısı, steroid enjeksiyonu

\section{Introduction}

Calcific tendonitis is a disorder caused by calcium deposits building up in muscles or tendons (1). Peak incidence of calcific tendinitis occurs in the fifth decade of life, and is almost exclusively found in adults older than 30 years (2). The most common site of calcific tendinitis is the supraspinatus muscle in shoulder. Less common locations include the hip, elbow, wrist, knee, and neck in order of frequency. The deposits may be located within the tendon or in the soft tissues adjacent to the tendon or ligament near its attachment to the bone. There is an acute inflammatory reaction, with pain, tenderness, and local swelling.
Calcific tendinitis in the gluteus medius is rarely seen (3). Although uncommon, it can cause significant morbidity affecting the patient's activities of daily living and ambulation. A case is here reported of acute tendinitis of the gluteus medius to enlighten clinicians about the characteristics of this unusual finding.

\section{Case Report}

A 39-year-old male presented with a severe right hip pain, which was exacerbated with activity, which had been ongoing for 2 weeks. There was no history of trauma. Physical examination revealed marked tenderness over the right greater trochanter 
and no limitation in hip range of motion. There was no loss of muscle strength in the lower extremity. There were no contributory findings and no laboratory abnormalities. On plain radiography, a calcific deposit was seen adjacent to the greater trochanter (Figure 1a). Magnetic resonance imaging (MRI) demonstrated inflammatory edematous changes in the insertion of the gluteus medius tendon to the greater trochanter (Figure 1b). A diagnosis of acute calcific tendinitis was determined and the patient was treated conservatively using nonsteroidal antiinflammatory drugs. The patient reported no reduction in pain after 1 week of drug therapy. Consequently, a corticosteroid injection to the lesion site was administered. The severe hip pain and tenderness over the greater trochanter decreased within 3 days

\section{Discussion}

Calcific tendinitis is a benign inflammatory condition occurring in numerous anatomic locations, most commonly around the shoulder. Involvement of the gluteus medius tendon is a rare occurrence (4). The reason for calcification of the tendons is unknown but proposed reasons have included post-traumatic post-operative and metabolic conditions.

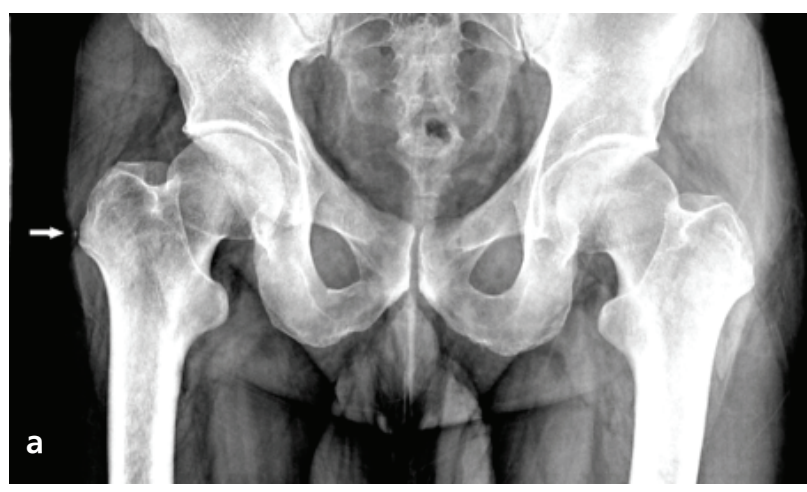

Figure 1a. Anteroposterior plain radiograph of the right hip reveals a soft tissue calcification (arrow) adjacent to the greater trochanter

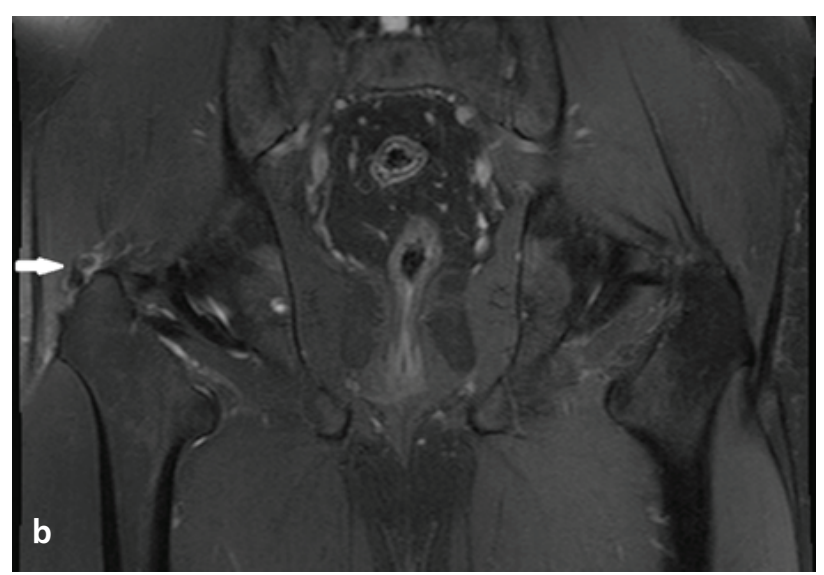

Figure 1b. Coronal T2-weighted image with fat saturation shows calcific deposit with neigbouring inflammatory edematous changes (arrow) in the insertion of the gluteus medius tendon to the greater trochanter
Calcific tendinitis usually occurs in a single joint and affects people aged 40-70 years. The most common symptoms are marked tenderness and pain aggravated by joint motion in the region of the origin of the tendons and in some cases there may be local edema, limitation in joint movement and elevated levels of acute-phase reactants. The severe pain associated with calcific tendinitis usually occurs during the resorptive phase, when there is vascular proliferation along the margin of the deposit, with infiltration of macrophages and multinucleated giant cells that digest the apatite crystals and release hyperalgesic cytokines (5). The diagnosis is based on clinical suspicion and radiographic findings of calcific deposits in the corresponding tendon (3).

The differential diagnoses of calcifications in the hip joint include septic arthritis, avascular necrosis, osteoarthritis, stress fractures, femoro-acetabular impingement, and avulsion fractures of the hip. In cases of diagnostic uncertainty, advanced imaging techniques such as computed tomography or MRI should be used. In the current patient, septic arthritis of the hip was excluded because there was no effusion in the hip joint and the white blood cells and acute-phase reactant levels were normal. Suspicious calcification areas adjacent to the great trochanter on plain radiography and inflammatory edematous changes in the insertion of the gluteus medius tendon obseerved on MRI were helpful in the diagnosis.

Clinical symptoms of calcific tendinitis usually diminish spontaneously. The treatment of calcific tendinitis usually involves non-steroid anti-inflammatory drugs, local injections, ultrasonic therapy or radiotherapy. When the symptoms progress and interfere with daily activities, open surgical removal is recommended. In the case presented here, as the patient was not responsive to non-steroid anti-inflammatory drugs, a corticosteroid injection was applied and the symptoms were resolved.

Acute calcific tendinitis is an important consideration in the differential diagnosis of acute hip pain. Radiographs are useful in confirming the diagnosis when symptoms and examination findings are characteristic.

The patient was informed that we wanted to submit data from his case for publication, and provided her consent.

\section{Ethics}

Informed Consent: A consent form was completed by all participants.

Peer-review: Externally and internally peer-reviewed.

\section{Authorship Contributions}

Surgical and Medical Practices: B.A., Concept: B.A., S.K., Design: B.A., Ü.G., Data Collection or Processing: B.A., E.Y., Analysis or Interpretation: S.K., A.K.T., Literature Search: B.A., S.K., Writing: B.A., S.K., E.Y.

Conflict of Interest: No conflict of interest was declared by the authors.

Financial Disclosure: The authors declared that this study received no financial support. 


\section{References}

1. Gondos B. Observations on periarthritis calcarea. Am J Roentgenol Radium Ther Nucl Med 1957;77:93-108.

2. Faure G, Daculsi G. Calcified tendinitis: a review. Ann Rheum Dis 1983:42(Suppl 1):49-53.

3. Sakai T, Shimaoka $Y$, Sugimoto M, Koizumi T. Acute calcific tendinitis of the gluteus medius: a case report with serial magnetic resonance imaging findings. J Orthop Sci 2004;9:404-7.

4. Kandemir U, Bharam S, Philippon MJ, Fu FH. Endoscopic treatment of calcişc tendinitis of gluteus medius and minimus. Arthroscopy 2003;19:4.

5. Uhthoff HK. Calcifying tendinitis: an active cell-mediated calcification. Virchows Arch A Pathol Anat Histol 1975;366:51-8. 